Научная статья

УДК 82.0

DOI 10.18101/2686-7095-2021-4-22-27

\title{
ТЕМА СЕМЬИ \\ В РОМАНЕ Ф. М. ДОСТОЕВСКОГО «ПОДРОСТОК»
}

\author{
(C) Серебрякова Зоя Александровна \\ доктор филологических наук, и. о. профессора, \\ Восточно-Сибирский государственный институт культуры \\ Россия, 670031, г. Улан-Удэ, ул. Терешковой, 1 \\ serebryakovaza@mail.ru
}

\begin{abstract}
Аннотация. В статье анализируется тема семьи главного героя романа Ф. М. Достоевского «Подросток». При соблюдении внешних приличий в ней сложные и противоречивые отношения. Если Софья беззаветно любит мужа, то у Версилова любовь парадоксально сочетается с пренебрежительностью. Непрочность семейного статуса определила робость и тревожность женщины. Аркадий, росший вне семьи и испытывающий унижения из-за своей незаконнорожденности, тянется к отцу, вдруг вспомнившему о нем и позвавшему к себе, знакомится с сестрой Лизой и матерью, память о редких встречах с которой бережно хранит в душе. Он ценит доброту Софьи и Лизы, чувствует себя сыном и братом. Виня себя за его долгое сиротство, мать опекает его. Версилов относится к сыну иронично, но их беседы помогают тому социализироваться. Аркадий с трудом включается в семью, но в итоге обретает ее.
\end{abstract}

Ключевые слова: семья, семейные отношения, семейный статус, любовь, антиномичность, родители, дети, роман, герой, проблема.

\section{Для цитирования}

Серебрякова 3. А. Тема семьи в романе Ф. М. Достоевского «Подросток» // Вестник Бурятского государственного университета. Филология. 2021. Вып. 4. С. 22-27.

Трудно переоценить влияние семьи, одного из самых ранних социальных институтов, на процесс становления личности и возможности ее самореализации. Входящие в нее люди, как правило, особенно, по-родственному близки друг к другу. Этому коллективу присуща «система связей, характеризующаяся потребностью людей друг в друге, взаимной ответственностью, единством основополагающих ценностей... В ней проходит большая часть времени, закладываются основы характера, усваиваются навыки общения, закрепляются социальные роли отца, матери и т. д., воспроизводятся другие аспекты жизнедеятельности человека и общества» [10, с. 69-70].

«Подросток» Ф. М. Достоевского не похож на классический семейный роман потому, что и семья его главного героя и повествователя Аркадия Долгорукого не классическая. Напротив, это «случайное семейство». Задумав произведение, автор планировал, в частности, анализ проблемы «детей и подростков, их отношений с обществом и семьей» [9, с. 377].

Эта задача была в полной мере решена писателем. Как верно отмечает А. В. Архипова, в «Подростке» «впервые с такой отчетливостью и резкостью поставлена тема распада старой семьи и возникновения на ее месте «случайного 
семейства». Достоевский действительно отразил начало этого процесса, настолько еще не осознанного русским обществом и не воплотившегося в русской литературе, что критика упрекала романиста в отсутствии правды, нарушении норм, изображении больного и неестественного» [1, с. 117].

Аркадий и его сестра Лиза - незаконнорожденные дети помещика Версилова и его бывшей дворовой Софьи. Их юридическим отцом считается бывший крепостной садовник Версилова Макар Долгорукий, ставший странником и живущий в отрыве от семьи. Никакого влияния на Аркадия, в том числе в конце своей жизни, Макар не оказывал.

В этом случайном семействе соблюдались внешние приличия: Софья с Лизой проживали отдельно от Версилова, Макар и Софья дважды в год обменивались ритуальными письмами с сообщениями о здоровье, пожеланиями, поклонами, упоминаниями имен детей, Макар раз в три года около недели гостил в формальной семье, «скромно помещаясь где-нибудь за перегородкой» [3, с. 18].

Рассмотрим, каковы отношения супругов, как выполняют они родительские функции, как дети относятся к ним и друг к другу.

Аркадий пытается выяснить причины, побудившие отца, молодого вдовца, вступить в связь с его матерью, вовсе не «вертушкой», а почтительной женой Макара. Версилов отвечает, что почувствовал к Софье жалость и привязался к ней как к воплощению души народа, его представительнице, при этом он видит разницу между народом и дворовыми, жившими во многом интересами господ. «Не ручаюсь, что он любил ее, но что он таскал ее за собой всю жизнь - это верно», — заключает юноша [3, с. 15].

Свойственная Версилову антиномичность характера, сочетающего злое и доброе, возвышенное и низменное, проявляется в его отношении к родным, которых он и ценит, и одновременно пренебрегает, с которыми он то мягок, то насмешлив до оскорбительности.

К моменту приезда сына и брата семья проживает, в отличие от прежних времен, совместно, хотя у Версилова есть и своя квартира. Заявляя, что ужасно не любит, когда женщины работают, он, к сорока пяти годам промотавший три больших наследства, допускает, что его жена и дочь должны трудиться. Лишенный светского общения из-за бесчестного поступка, он, не бросая дорогих привычек и «капризничая», бездельничает.

Об отношении мужа к Софье говорят поступки. Он на полгода оставил в Кенигсберге не знающую языка и не имеющую денег (просто забыл их оставить) женщину с малышкой на руках, пока приехавшая Пруткова, соседка Версилова по имению, не вывезла бедняг на родину. Одну из встреч с Аркадием Софья предприняла самовольно, почти тайком, когда на свои жалкие средства приехала в московский пансион. Сын поражается, как могла мать жить с отцом, пренебрежительность которого к жене сочетается с тем, что К. В. Мочульский называет «Глубокой сострадательной любовью» [6, с. 481]. Свое чувство Версилов осознал только в Германии, и Аркадий считает его скорее «гуманным и общечеловеческим», нежели обычной, «простой любовью, которою вообще любят женщин» $[3$, c. 491$]$. 
В то время как Софья бедствовала в Кенигсберге, муж, обуреваемый сонмом идей и захотевший «разжениться» с ней, вращался в свете и планировал женитьбу на молодой девушке Лидии Ахмаковой.

Клянясь, что жена лучшая из женщин, что он не встречал никого с таким тонким и догадливым сердцем, что она его единственная царица (хотя сын чувствует, что мать несчастна), Версилов после смерти Макара нарушает данное тому «дворянское слово» обвенчаться с Софьей, когда она овдовеет, и в финале романа это слово так и остается пустым обещанием.

Что мотивировало мать беззаветно полюбить Версилова, остается для центрального героя загадкой. Между тем ее будущее всегда было неопределенным. Она даже дала согласие на женитьбу Версилова на Лидии, но смерть невесты не дала осуществиться этой его выходке.

Непрочность статуса сказалась на поведении Софьи, выразилась в приобретенных ею страхах, тревожности, зачастую из-за пустяков, беспричинной пугливости. Так, она не смеет без разрешения Версилова принять от Аркадия деньги. Положение Софьи осложняется тем, что Версилов много лет питает неодолимую страсть-ненависть к молодой вдове Катерине Ахмаковой, перипетии отношений с которой влияют на его отношение к жене.

Несовместимым с элементарными представлениями о семье было положение наследника: «Я был как выброшенный и чуть не с самого рождения помещен в чужих людях... просто как-то так почему-то вышло». Аркадий домыслил, что молодая и привлекательная жена оказалась нужной Версилову, а ребенок был помехой, особенно в путешествиях. «Вот так почему и случилось, что до двадцатого года я почти не видал моей матери, кроме двух-трех случаев мельком. Произошло не от чувств матери, а от высокомерия к людям Версилова» [3, с. 18].

Выброшенный в чужую среду, Аркадий «противостоит ей как одиночка, а не как член другого коллектива, осознавший свою групповую принадлежность через личные связи» [8, с. 55]. Такой группой чаще всего выступает семья, а у него ее долго не было. Между тем, «самым близким окружением человека с момента рождения является семья. В качестве таковой она в большинстве случаев является и все последующие годы жизни. В семье происходит воспитание и формирование ребенка, развитие его способностей и интересов. В семье ребенок усваивает нормы морали и поведения, получает представления об окружающем мире...» [7, с. 26]. Отсюда трудности героя в общении с людьми, инфантилизм, несдержанность и т. п., которые он объясняет тем, что «вырос в углу», что вызвало стремление «закупориться еще больше в угол» [3, с. 32].

Молодой человек постоянно стесняется или раздражается, когда Версилова называют его отцом, когда величают его то Макаровичем, то Андреевичем, подозревает собеседников в презрении к себе за незаконнорожденность, за то, что он сын дворовых, слышит, что у него нет фамилии, сам говорит об этом.

Более двух лет подвергаясь из-за своего происхождения побоям и издевательствам в пансионе, он мечтал, что сбежит, что отец заберет его, фантазировал, где тот находится. Мальчик не подозревал, что Версилов не знал, где прошло детство сына, не помнил о нем. Спустя девять лет он еле-еле, после подсказок, вспомнил их встречу. Высокомерие и равнодушие главы семьи к ее членам 
убеждают Аркадия, что тот никогда не любил и не любит их, но речи отца заставляют сомневаться в этом.

Переживания Аркадия переданы с присущим автору мастерством. «Главная особенность гениального психологического анализа Достоевского заключается в умении раскрыть противоречия и борьбу чувств и мыслей в одном персонаже, раздвоение человека, натура которого извращена и искажена социальными условиями», — пишет А. А. Белкин [2, с. 49].

Отец, вдруг вызвавший сына в себе, весьма спесив, насмешлив, ироничен с ним, как с «самым зеленым подростком», хотя признает и его достоинства, например чистоту души, которой сам с сумбурным, раздвоенным и «мутным» внутренним миром ни в коей мере не обладает. Об отсутствии заботы о детях свидетельствует то, что и родные дети Версилова выросли у родственников. Повзрослев, они отвернулись от него в связи со скандалом, закрывшим для него светское общество.

Отношение Софьи к первенцу ему непонятно: с одной стороны, послушная мужу, она мирилась с жизнью вдали от ребенка. Возможно, это объясняется ее пассивностью, проявившейся в том спокойствии, с которым она выходила замуж, за что Пруткова даже обругала ее рыбой. С такой же покорностью, названной В. Кирпотиным добродетелью «неделания, пассивизма, примирения с сущим, страха перед изменениями» [5, с. 600], Софья приняла разлуку с Аркадием. С другой стороны, он припоминает, что мать была ласкова, а через годы она четко помнит, когда виделась с ним.

С взрослым сыном она робка, осторожно приглядывается к нему, а он обнаруживает в ней такую чистоту души, которую «даже трудно себе и представить» [3, с. 16]. Софья винится, что не знала его, но он считает, что во всем виноват отец.

Главный герой относится к родителям по-разному. В. Кирпотин пишет, что «силы души Подростка были прикованы преимущественно к отцу», к которому он испытывал «противоречивую, мучительную и сладостную тягу». В конце концов, он «затянулся в дела Версилова целиком» [5, с. 588]. Тот, поразив десятилетнего мальчика уже при первой случайной, но памятной встрече, имел «капитальное влияние на склад всей души» сына. Отец дорог ему, и Аркадий так стремился помочь ему восстановить честь, что тот «наполнял собою» все его будущее, всегда оставаясь при этом «загадкой» [3, с. 19, 77, 23].

Юноше открываются и его неприятные качества. Одно из них - мелкая мстительность: на слова сына о том, что Версилов слишком постарел за девять лет, тот отвечает, что и Аркадий «тоже проиграл» за это время. Но доминирующей негативной чертой главы семьи является самолюбие: «Версилов ни к какому чувству, кроме безграничного самолюбия, и не может быть способен!» [3, с. 288].

Аркадий сохранил о матери более теплое, чем об отце, хотя и не такое восторженное воспоминание: «Ничего не помню и не знаю, но только что-то осталось от вашего лица у меня в сердце на всю жизнь, и, кроме того, осталось знание, что вы моя мать..., а вас ...помню ясно только в одном мгновении, когда меня... раз причащали и вы приподняли меня принять дары и поцеловать чашу... Ваше лицо или что-то от него, выражение, до того у меня осталось в памяти, что 
пять лет спустя... я тотчас признал вас, хоть мне никто не сказал тогда, что вы моя мать» [3, с. 114-115].

При появлении Софьи в пансионе он, третируемый соучениками и предвидя их насмешки, стыдился ее одежды, грубых рук, простоты поведения, поклонов, но по ночам вспоминал и мысленно говорил с нею.

Взрослый сын жалеет, любит мать, ценит ее доброту, чуткость, терпение, самоотверженность, застенчивость, целомудренность. Ему симпатично милое, лишенное грусти и ущемленности лицо. Преодолев неловкость, он впервые здоровается и называет ее мамой, отчего она тоже теряется. Не смея грубить отцу, он срывается на ней, с готовностью прислуживающей ему и обращающейся $\mathrm{\kappa}$ нему на «вы». Она покорно сносит его выходки, лишь молча умоляя его не конфликтовать с Версиловым.

Никогда не видевший сестру, юноша видит в ее характере много общего с матерью. Лиза, жившая вблизи отца, зовет его папой, но Аркадий не хочет этого делать. Лиза сдерживает брата, просит щадить мать и быть терпеливым с Версиловым. Полюбившая слабого духом, попавшегося в тюрьму князя Сергея Сокольского, гордая, но кроткая и смиренная Лиза замкнулась после его смерти в своем горе и одиночестве.

Видя, что дети, малознакомые и разные из-за условий воспитания, трудно привыкают друг к другу, Софья может лишь посоветовать им «любить друг дружку» и выразить надежду, что «бог счастья пошлет».

Художественный анализ бытия семьи в контексте всегда актуальной проблемы отцов и детей завершается самым оптимистическим из всех романов Достоевского финалом: «хотя для «отцов», для Версилова, поиски кончились он успокоился возле матери Подростка... Для Подростка еще все впереди, вся новая жизнь, и новые поиски, и новые «идеи» [4, с. 70].

Таким образом, родительские функции Версилов и Софья до приезда Аркадия выполняли лишь по отношению к Лизе. Постепенно, с трудом они пытаются стать отцом и матерью и для сына. Он же драматически переживает процесс включения в семью, но в итоге обретает родных для себя людей.

Лuтература

1. Архипова А. В. «Подросток» в творческом восприятии Александра Блока // Достоевский: материалы и исследования / АН СССР, Ин-т русской литературы (Пушкинский дом); редактор Г. М. Фридлендер. Ленинград: Наука, Ленингр. отд-ние, 1978. Т. 3. С. 114-125. Текст: непосредственный.

2. Белкин А. А. О реализме Достоевского // Творчество Достоевского. Москва: Изд-во АН СССР, 1959. С. 45-54. Текст: непосредственный.

3. Достоевский Ф. М. Подросток. Москва: Гос. изд-во худ. лит-ры, 1961. С. 7-582. Текст: непосредственный.

4. Ермакова М. Я. Романы Достоевского и творческие искания в русской литератуpe XX в. Горький: Волго-Вятское кн. изд-во, 1973. 320 с. Текст: непосредственный.

5. Кирпотин В. Роман Достоевского «Подросток» // Достоевский Ф. М. Подросток. Москва: Гос. изд-во худ. лит-ры, 1961. С. 583-609. Текст: непосредственный.

6. Мочульский К. В. Достоевский // Гоголь. Соловьев. Достоевский. Москва: Республика, 1995. С. 219-549. Текст: непосредственный. 
7. Осинский И. И., Гылыкова Э. В. Бурятская городская семья на рубеже XX-XXI веков: социологический анализ. Улан-Удэ: Изд-во Бурят. гос. ун-та, 2003. 352 с. Текст: непосредственный.

8. Семенов Е. И. Роман Достоевского «Подросток» (проблематика и жанр). Ленинград: Наука, 1979. 168 с. Текст: непосредственный.

9. Сыроватко Л. В. Подросток // Энциклопедия мировой литературы. СанктПетербург: Новая книга, 2000. С. 376-379. Текст: непосредственный.

10. Чимитова И. 3. Семья как фактор формирования и укрепления межэтнического согласия в Республике Бурятия // Вестник Бурятского государственного университета. Сер. Философия, социология, политология, культурология. Улан-Удэ, 2015. Вып. 14. С. 69-74. Текст: непосредственный.

Статья поступила в редакцию 19.11.2021; одобрена после рецензирования 29.11.2021; принята к публикации 10.12.2021.

\section{THEME OF THE FAMILY IN FYODOR DOSTOEVSKY'S NOVEL "THE ADOLESCENT"}

Zoya A. Serebryakova

Dr. Sci. (Phil.), A/Prof.,

East-Siberian State Institute of Culture

1 Tereshkovoy St., Ulan-Ude 670031, Russia

serebryakovaza@mail.ru

Abstract. The article analyses the theme of the family in Fyodor Dostoevsky's novel "The Adolescent". The protagonist's family seems to be secured, but its members have uneasy relations relations and conflicts. Sofya selflessly loves her husband, but Versilov's love is paradoxically combined with dismissiveness. Incertitude of the family status determined the women's diffidence and anxiety. Arkady, who has grown up outside the family and experienced indignity because of his illegitimacy, wants to be closer to his birth father, who has suddenly remembered about him. Arkady meets his sister Lisa and his mother, appreciates the kindness of Sofya and Lisa, and feels himself a son and a brother. Blaming herself for his long orphanhood, his mother takes care of him. Versilov treats his son with irony, but their talks help him socialize. Arkady hardly joins the family, but eventually he retrieves it.

Keywords: family, family relations, family status, love, antinomy, parents, children, novel, the character, problem.

\section{For citation}

Serebryakova Z. A. Theme of the Family in Fyodor Dostoevsky's Novel "The Adolescent”. Bulletin of Buryat State University. Philology. 2021; 4: 22-27 (In Russ.).

The article was submitted 19.11.2021; approved after reviewing 29.10.2021; accepted for publication 10.12.2021. 